\title{
Firm Exit and Armed Conflict in
} Colombia

\author{
Adriana Camacho \\ and Catherine Rodriguez*
}

August 2010

\begin{abstract}
This paper uses two unique panel data sets to study the causal effect that armed conflict has over entrepreneurial activity in Colombia. Using a fixed effect estimation methodology at the plant level and controlling for the possible endogeneity of armed conflict through the use of instrumental variables, we find that a one standard deviation in the number of guerrilla and paramilitary attacks in a municipality increases the probability of firm exit in 8.1 percentage points. This effect is stronger for smaller plants and has a differential impact with respect to firms' age.
\end{abstract}

Keywords: conflict, firm exit, entrepreneurship, Colombia

JEL classification: D21, J31, R30

Copyright (C) UNU-WIDER 2010

* Universidad de Los Andes, Department of Economics, corresponding author: cathrodr@uniandes.edu.co.

This study has been prepared within the UNU-WIDER project on Entrepreneurship and Development (Promoting Entrepreneurial Capacity), directed by Wim Naudé.

UNU-WIDER gratefully acknowledges the financial contributions to the project by the Finnish Ministry for Foreign Affairs, and the financial contributions to the research programme by the governments of Denmark (Royal Ministry of Foreign Affairs), Finland (Finnish Ministry for Foreign Affairs), Sweden (Swedish International Development Cooperation Agency_Sida) and the United Kingdom (Department for International Development-DFID). 


\section{Acknowledgements}

Research assistance from Alejandro Hoyos and Román Andrés Zárate is gratefully acknowledged. Adriana Camacho thanks Departamento Administrativo Nacional de Estaditicas (DANE) for providing the Annual Manufacturing Survey Data. Comments welcome. All errors are ours.

Tables and figures appear at the end of the paper.

The World Institute for Development Economics Research (WIDER) was established by the United Nations University (UNU) as its first research and training centre and started work in Helsinki, Finland in 1985. The Institute undertakes applied research and policy analysis on structural changes affecting the developing and transitional economies, provides a forum for the advocacy of policies leading to robust, equitable and environmentally sustainable growth, and promotes capacity strengthening and training in the field of economic and social policy making. Work is carried out by staff researchers and visiting scholars in Helsinki and through networks of collaborating scholars and institutions around the world.

www.wider.unu.edu publications@wider.unu.edu

UNU World Institute for Development Economics Research (UNU-WIDER)

Katajanokanlaituri 6 B, 00160 Helsinki, Finland

Typescript prepared by Lisa Winkler at UNU-WIDER

The views expressed in this publication are those of the author(s). Publication does not imply endorsement by the Institute or the United Nations University, nor by the programme/project sponsors, of any of the views expressed. 


\section{Introduction}

In a recent study, Harbom and Wallensteen (2007) report that a total of 232 armed conflicts have been active in 148 locations since the end of the Second World War. This high incidence of armed conflicts around the world has significantly increased academic research on the possible impact of violence on several outcomes of interest. Most of this research has focused on the direct impact that conflict has on its victims and on the households residing in conflict areas. The questions in these studies include the impact of violence on forced migration (Morrison and May 1994; Ibañez and Velez 2005), households' consumption and investment patterns (Verwimp and Bundervoet 2008; Grun 2008), general health of individuals (Camacho 2008), and on the levels of education attainment and labor decisions of children exposed to conflict (Shemyakina 2006; Rodriguez and Sanchez 2009), among others.

However, little attention has been given to the impact that conflict may have on firms' decisions, performance, and activities. This is strange, given the importance that entrepreneurship and firms' activities have on the economic performance in a country. Moreover, authors such as Iyigun and Rodrik (2004) and Munshi (2007), suggest that low levels of development are in part caused by low levels of entrepreneurship. Understanding if and how conflict affects economic activity at the firm level could provide governments and NGOs with insights on how to reduce the impact of conflict on economic activity and the development of a country.

Among the few studies that have addressed the problem of firm activity and civil conflict we find Barro (1991) and Alesina and Perotti (1996). Using cross-country data, both studies show a negative relationship between political stability and economic growth. Similarly, Gaviria (2002) shows that firms' sales in Latin America grow at a lower rate if entrepreneurs believe crime rates are at sufficiently high levels to interrupt business. Of course, this cross-country evidence, although suggestive, may suffer from omitted variable bias and reverse causality between poverty and conflict if not adequately controlled for. Hence, recent studies have focused on single country information in order to reduce these estimation problems. For instance, Abadie and Gardeazabal (2003) used information in the Basque Country to estimate the impact that terrorist activities have on GDP, while Pshisva and Suarez (2006) established the negative impact that kidnaps have on firms' investment decisions in Colombia.

This paper enriches the existing literature by estimating the effect that armed conflict has on exit decisions of manufacturing firms. To do so, we use information from two unique panel data sets from Colombia that allow us to directly link firms' activities with armed conflict intensity at the municipality level. We believe Colombia is an appropriate country, given that it suffers from one of the longest internal conflict still present today. Guerrilla and paramilitary groups have been active since the 1960s; they have committed several attacks in most of its national territory and with very high intensity during the 1990s, affecting in a negative and significant manner most of its population. These attacks have varied in intensity and geographical location during the years and hence provide sufficient variation to capture its effect on economic activity. 
The information on entrepreneurial activities used in the present study comes from the Annual Manufacturing Survey (AMS). This is a census of manufacturing plants with more than ten employees or annual production above 115.5 million pesos measured in 2005 prices (around US\$46,000) for the period 1993-2005. Information on armed conflict is obtained from a yearly data set at the municipal level constructed by CEDE (Centro de Estudios sobre Desarrollo Económico-Universidad de los Andes) which contains the number and types of attacks perpetrated by both guerrilla and paramilitary groups in Colombia between 1988 and 2004. Our conflict measure is the sum of all attacks perpetrated by all the active armed groups in each municipality. This information is further complemented with information on government deterrence measures.

We use three different approaches in order to obtain the causal link between armed conflict and firms' exit decisions. The first one uses a panel-fixed effect estimation at the plant level where the contemporaneous armed conflict measure is our independent variable of interest. To control for possible endogeneity, the second approach uses a lagged armed conflict measure instead of the contemporaneous one. Our third and preferred strategy is an instrumental variable approach in which contemporaneous armed conflict is instrumented with lagged government deterrence measures. 1 Under this last methodology we find that the average violence increases the probability of firm exit in six percentage points. If we evaluate this same effect with an increase in one standard deviation of the rate of attacks present in the municipality there is a positive and significant increase over the hazard that a firm exits of about 8.1 percentage points. Moreover, we find that this effect differs according to plants characteristics. Specifically, smaller firms are more likely to exit when civil conflict increases. Results show that violence also has a differential effect according to firms’ age.

There are several differences between the previous research above mentioned and the one we present in this paper making an important contribution to the literature. The first one is related to the use of information from a single country with enough armed conflict variation. As known, this will reduce problems such as omitted variable bias, reverse causality, and measurement errors. 2 Second, no study before has linked firms' plant level data with violence data at the municipality level. 3 While Pshiva and Suarez (2006) use firm data level the linkage is only at the state level and they concentrate only on one type of crime. Furthermore, the information used in the cited study corresponds to general balances of the firms; this information reports the location of the firm as the place where it is registered. However, the place where the firm is registered is not necessarily the place where the firm operates, especially if firms have several production plants under the same

1 The intuition for choosing these instruments is closely related with recent research by Angrist and Kugler (2008). This will be explained in more detail later.

2 On this last point, some of the studies in the literature use perception based crime or conflict levels that are not always necessarily accurate. Moreover, studies that use more formal crime or conflict measures may be difficult to interpret given the differences in registry and measurement of crime in different countries. We do not face such problems given that we use the same measure of armed conflict along the years for Colombia.

3 Colombia has 31 states and 1120 municipalities within those states. 
name. In our sample, we find that approximately 10 percent of the firms have more than one plant. This could measure how much firm misallocation could appear in the Pshiva and Suarez (2006) study. In our study we are able to match plant level information with violent acts committed directly in the municipality where the firms' production plants are located.

Third, the available data allows us to study the impact of violence on an entrepreneurial aspect that, as stated by previous authors, crucially determines the landscape of the economy, its jobs and development, but was not studied before: plant exit. We therefore provide a crucial link through which armed conflict affects economic development and growth at the micro-economic level. Last, but not least, the rich data available allows us to explicitly take into account the possible endogeneity of armed conflict through an instrumental variables approach which has never been carried out at the firm level before.

Given our question of interest, this paper is also related to the literature that studies the determinants of firm exit decisions in different contexts. For instance, Alvarez and Görg (2009) and Bernard and Jensen (2006) study how foreign ownership affects plant deaths in Chile and the USA, respectively. Similarly, under a duration analysis framework, Audretsch and Mahmood (1995) find that survival rate not only depends on age and firms' size, but it is also affected by the innovation rate at the industry level, capital intensity, and new firms with new branches. Even though all of these studies had information at the plant level they only controlled for industry-fixed effects. Finally, we should also mention the work by Eslava et al. (2004, 2008) who have studied plant exits in Colombia during the 1990s. Their papers use information from AMS, the same source of information this paper uses. However, their focus is different since they relate plant exit to the major labor, trade, and financial reforms that occurred early in that decade, but do not control for the violence the country experienced during these years. Furthermore, we use slightly newer information that accounts for the years after the reforms took place and control for year-fixed effects to capture any reform done after 1993.

\section{Literature Review}

Most of the existing literature on the consequences of conflict on economic activity has focused on cross-country evidence at the aggregate level. The first studies undertaken by authors such as Barro (1991), Alesina et al. (1996), and Alesina and Perotti (1996) focused on analysing how political instability affected investment rates and economic growth at the national levels. Using cross-country data and different definitions of political instability or conflict, these authors find a negative relationship between these variables and economic activity. Similarly, Collier (1999) estimates that during conflict periods countries' growth is approximately 2.2 percent lower than that obtained in peaceful times. Moreover, Stewart et al. (2001) find that 15 out of 16 countries that have experienced an internal conflict within its borders suffered a decrease in their GDP per capita.

In a more recent study, instead of using aggregate data at the country level, Gaviria (2002) used information provided by around 100 middle and top managers from the private sector in 29 different countries. Controlling for firms' characteristics as well as country-fixed effects, the author finds that both perceived corruption and crime have a negative and 
significant effect on investment and employment growth at the firm level. Although Gaviria investigates both corruption and crime activity, it is worth noting the apparent importance that the former has compared to the latter. First, according to 53 percent of the interviewed managers, crime is an obstacle to doing business compared to 46 percent who think corruption is an obstacle.4 Second, his empirical strategy suggest that while corruption lowers sales growth by 30 percent, crime reduces it by 35 percent. Similarly, while corruption appears to have no effect over investment, crime reduces it by 16 percent.

Of course, this cross-country evidence although suggestive may suffer from some limitations such as measurement error, omitted variable bias, and reverse causality between poverty and conflict if not adequately controlled for. Hence, recent studies have tried to solve these problems by using information regarding conflict in a single country in order to study its possible economic impact. Among these studies we find Abadie and Gardeazabal (2003) who evaluate the economic effects that terrorist activity performed by ETA has imparted in the Basque Country since its outset in the early 1970s. To do so, the authors carry out two different methodologies. In the first they construct a synthetic control region that should have a very similar economic potential to the one from the Basque Country before the conflict. They compare the economic evolution of this fictitious region with the actual path the Basque economy had. They find that the terrorist activity created a gap of almost ten percentage points between both measures of GDP per capita. In their second approach, the authors use the unilateral truce the terrorist group declared for one year in 1998 and evaluate the performance of Basque companies' stocks relative to the ones from other Spanish companies. They find the former outperformed non-Basque stocks during the period while the truce was credible.

Even though there is a great potential for studying the effect of conflict in Colombia, Riascos and Vargas (2004) mention that there are few studies that estimate the impact that both violence and armed conflict have on economic growth. The first studies in the country by Rubio (1995) and Trujillo and Badel (1997) estimated the economic costs of conflict through accounting techniques and concluded that the total costs of armed conflict and illegal activities in the country amounted to 15 percent of the GDP. More recent research have used either time series information for the country (Querubin 2003; Vargas 2003; Cárdenas 2007), or have calibrated theoretical models to Colombian data (Arias and Ardila 2003; Mejia and Posada 2003). However, all of these papers used aggregate level data such as GDP per capita or its growth rate.

To the best of our knowledge, the only papers in the literature that relate conflict variables with firm level data for a single country are Pshisva and Suarez (2006) and Rettberg (2008). The latter carries out a survey on nearly 1,000 firms in Colombia's six biggest cities asking their managers how armed conflict has influenced their operations. Through a descriptive methodology the author concludes that armed conflict in Colombia affects its firms through channels such as transaction costs, investment, expansion opportunities, and firm sales. Pshisva and Suarez (2006) use firm level panel data comprising nearly 10,000 firms for the period 1996-2002 and combine it with information on the number of kidnappings at the

4 This percentage increases to 67 percent for managers residing in Latin American countries. 
state level in Colombia. The authors estimate the effect that kidnaps have on firms' investment decisions under an OLS framework with fixed effects at the firm level. They find that a one standard deviation increase in firm-targeted kidnappings reduce the investment rate of the average firm from 0.29 percent to -0.28 percent of total assets. The authors suggest that the channel through which the effect of kidnaps are transmitted to investment is fear, and not demand, costs, or credit constraints.

Even though previous researchers have studied the impact of armed conflict on economic activity none have used such detailed data as the one we use in this paper. The special and unique characteristics of the data used as well as the estimation strategies makes the present paper a contribution to the literature. Moreover, no study before has investigated the impact of armed conflict on firm exit decisions.

\section{Data}

In order to answer our research questions we use Colombian violence and firm level data. Colombia has two detailed and unique data sets that will allow us to study in depth how armed conflict affects entrepreneurial activity.

\subsection{AMS 1993-2005}

The Colombian AMS is conducted by the National Department of Statistics DANE starting 1982 and ending 2005. This is a census of industrial plants with more than ten employees, or production above 115.5 million pesos in 2005 (this value is adjusted every year using the Producer Price Index). 5 This is a unique data set of which one can construct a panel of firms by industry sectors over a long period of time. We will use information by year-plant on: wages and benefit payments, investments, value added of production, and entry and exit of manufacturing plants.

The information we use in this paper relates to the years 1993-2004. We start our panel 1993 because only from then on there is information about location (municipality) of the plant. Moreover, in 1992 DANE changed the coding of the plants and even though one could try to identify each plant of the new survey with past information some observations are lost and the methods are not anymore reliable, as documented by Eslava et al. (2004). With these restrictions in mind, we obtain a non-balanced panel including 12,714 plants during the period 1993-2004, accounting for 93,188 observations. These plants are located in 296 municipalities out of 1,120 municipalities of Colombia; they are well spread within the territory. Of course, most of the plants are located in big cities such as Bogota, Medellín, Cali, Barranquilla, and Bucaramanga where almost 65.23 percent of the sample are concentrating. The remaining firms are located in 28 of the 32 states in Colombia.

Table 1 shows a stable distribution of plants across years, with an average of approximately 7,765 firms per year. We also include descriptive statistics of the number of plants that exit

5 In US\$ this amounts to approximately US\$46,000 using an exchange rate of COL\$2,500 Colombian pesos per US\$. 
each year, with an average of 452. As observed, approximately 6 percent of all manufacturing firms in Colombia exit each year. Two important facts in our definition of exit should be noted. First, the survey is carried out to all plants with more than ten employees or with a production of above a given range. It could be the case that for a given year the plant had a lower number of employees, but the Statistics Department follows them to make sure they do not disappear from the panel until this condition of less than ten employees persists for more than three years. To make sure that we are not erroneously capturing such cases as exits we carried out all the empirical exercises with and without these small firms. All the results hold with this sample. 6 Moreover, we only assume there is an exit if we never see the plant in the survey again, so we allow for the possibility of firms that are not followed for a year but then they reappear in the sample with the same identification number.

In Table 2 we include statistics coming from the AMS for our dependent variable, firm exit, and for each of our control variables used in the empirical exercises such as: wages and benefit payments, investments, and value added of production. Across the decade we find that on average 5.83 percent of firms exit our sample, wage paid to production workers is 480,325 (2004 pesos) and for sales workers is 897,650 (2004 pesos), which corresponds to 1.34 and 2.51 of the 2004 minimum wage, respectively. Wages and investments are 16 percent and 17.5 percent of total value added, respectively. We believe that these data does not have much biases in terms of firm selection, given that Law 79 of October 1993 requires firms to fill out any survey provided by DANE. Moreover, every year DANE verifies with Confecamaras to send forms to new firms that qualify into the AMS, firms that will potentially enter into the panel receive pre-surveys to verify their characteristics to enter into the sample.

\subsection{Armed Conflict Data Base 1993-2004}

The Colombian conflict is one of the longest ongoing domestic confrontations in the world surpassed in length only by the Israeli-Palestinian and the Indian-Pakistani conflicts. There are three main irregular armed groups acting inside its borders. Specifically, there are two guerrilla organizations known as the Revolutionary Armed Forces of Colombia (FARC) and the National Liberation Army (ELN) both of which even though originated in communist ideas in the early 1960s are now also involved in drug producing and trafficking operations. The third group is a rightwing paramilitary group known as the United SelfDefense Forces of Colombia (AUC) founded almost 25 years ago and which is now under a peace process with the government. All three groups, besides engaging in direct fight with the national army, also perpetrate crimes against the civil population, private assets, and public infrastructure. To finance themselves and try to get political power they kidnap both for extortive or political reasons and engage in drug production and trafficking.

The information on this conflict used in this research comes from a balanced panel at the municipality level from 1988-2004, this data set has been collected along the years through

6 Although not presented in the paper, these results are available upon request. 
different sources by CEDE at Universidad de los Andes. 7 It has information on all attacks carried out by guerrillas and paramilitary groups; as well as deterrence and defensive actions taken by the government during this period.

Our measure of conflict in this research will be the total number of attacks carried out by the armed groups against civilians, their private assets or the public infrastructure. Specifically, the total number of attacks will be the sum of explosive terrorist attacks, arsonist terrorist attacks, private property assaults, entity terrorist attacks, political terrorist attacks, route blocking, armed contact, ambushes, harassing, population incursions, other terrorist attacks, land piracy, and illegal road blockings. To get an idea of the variation in the intensity of the civil conflict inside Colombian borders, Figure 1 presents the average rate of attacks in each municipality between the years 1993-2008. From this Figure it is clear that conflict is widespread all over the country. Moreover, it varies in intensity across regions. It is precisely this source of variation that will allow us the identification of the effects of armed conflict on firm exit decisions.

The average rate of attacks per 100,000 inhabitants in the municipalities where the firm plants in the AMS are located is depicted in Figure 2. This measure significantly increased after 1999 and only appears to start to decrease in 2004. Such pattern is consistent with the onset of President Uribe's first term when the country was in a deep civil war and both guerrilla and paramilitary groups were active and very strong. Table 2 also presents the average of 2.42 and standard deviation of 3.14 for this measure of conflict. As can be observed, the latter is almost 30 percent higher than the mean suggesting that armed conflict intensity varies widely across Colombia.

Table 2 also presents the average anti-narcotics operations as well as the number of drug laboratories dismantled by the army, navy, or the national police. On average there are 6.8 anti-narcotics operations in each municipality and 1.2 laboratories dismantled per year. As will be explained in more detail later, these variables are of interest, because they will be used as instruments for the total attack rate, given that they proxy for deterrence actions from the government. As previously mentioned, all Colombian armed groups use drug production and distribution as a major financing source. Hence, higher values of such operations will necessarily be associated with a higher presence of government, police forces, and criminal groups in the municipality. This in turn will imply that deterrence actions should be highly correlated with armed conflict measures.

\subsection{Municipal Controls}

After merging the above data sets described, we included additional variables that could help us control for some fixed characteristics at the municipality level different from the level of violence. Among them we include the town surface with an average of $843.97 \mathrm{~km}^{2}$ and an average distance of $53.57 \mathrm{~km}$ to the largest city in the municipality. Additional

7 Data was collected from Departamento Nacional de Planeación (DNP), Departamento Administrativo Nacional de Estadistica (DANE), Policía Nacional, Departamento Administrativo de Seguridad (DAS) and Centro de Estudios sobre Desarrollo Económico (CEDE) among others. 
descriptive statistics of these variables are presented in the last two lines of Table 2. We also include information that varies at the municipal level and overtime such as: government transfers received by each municipality and GDP levels of the State for each year. Their most relevant statistics are also presented in Table 2.

\section{Changes in Entrepreneurial Activity Due to Violence}

There are several channels through which armed conflict could interfere in the productive and commercial activities of the firm. One of the most named channels is that of uncertainty or fear. Naturally fear could reduce investment in both factors of production, labor and capital. As documented by Ibañez and Velez (2005) armed conflict could also affect firms' employment if laborers flee the region due to fear of being killed. In some cases, it could also happen that some civilians may even join the armed groups if they are offered higher wages than those obtained in the legal market. To summarize, the amount of labor supply could vary in different ways: it could depend on the rate of within and between forced migration. Firms located in urban areas of municipalities which have migration from rural to urban areas will see their labor force increase. Firms located in areas where migration happens from rural and urban areas to other municipalities, could see a reduction in their labor force.

Another direct impact of conflict may be related with changes in operational costs. It is plausible to imagine situations in which plants that are located in a violent area would need to increase security if private property is subject to acts of violence. In such cases either additional guard(s) or security systems need to be hired or implemented. Likewise, it could be the case that armed groups charge private firms extortion payments with the threat that if not paid direct terrorism acts could be aimed at the firms. Theoretically, such possibility has been previously analysed by Konrad and Skaperdas (1998). 8

Indirect effect for the firms may be numerous too. From the demand side, previous authors such as Verwimp and Bundervoet (2008) have shown that households' consumption growth is reduced under conflict. Hence, it is no surprise that demand for products or services produced by the firms could be reduced and hence probably production, and sales would decrease, too. Moreover, the reduction in investment, production and sales could in turn reduce the number of laborers firms will want to hire. Finally, another indirect effect that could take place is an increase in credit costs or a reduction in available loans to firms. It is plausible that banks will be willing to lend money to firms located in violent regions only at higher rates so that the higher risks that such loans entail are covered. In extreme cases banks will simply close all the credit lines for such regions.

8 Specifically, for Colombia a recent example of such bribes is that supposedly made to Blockbuster by a guerrilla group. The multinational company refused to pay them the demanded bribe and on 27 January 2009 a bomb in one of its stores was exploded in Bogotá. (More details in El Tiempo, 28 January 2009 'Autoridades atribuyen a extorsión atentado que dejó dos muertos en Bogotá') 
Through their influence in capital investment, labor hiring opportunities, changes in costs of production and effective customers' sales armed conflict could have a significant effect on a firm's exit decision. We can formalize these ideas using a simple model of firms' decisions where we abstract from the impact of armed conflict on the supply of factors of production. Let us assume that the firm $i$ in municipality $m$ at time $t$ produces with a traditional Cobb-Douglas production function that depends positively on the amount of capital $(k)$ and labor $(l): Y_{i m t}=A k_{i m t}^{\alpha} l_{i m t}^{1-\alpha}$ where $Y$ represents its production, $A$ captures its production technology and $\alpha$ a constant between zero and one.

Given the channels mentioned above, we will assume that violence could potentially affect investment in capital in each period.9 Specifically, if there is no armed conflict the value of the firms' capital in period $t$ will be its depreciated capital stock from previous periods plus any investment done in period $t$. Under a conflict a firm's capital will be a proportion $\lambda$ of that same amount of capital where $\lambda$ is a parameter between 0 and 1 that varies in magnitude according to the intensity of the violent attack that could destroy partially or totally the capital owned by the firm.

Under these assumptions, the expected value of firms' $i$ output will be given by:

$$
Y_{i m t}=\left(1-p\left(v_{m t}\right)\right) A k_{i m t}^{\alpha} l_{i m t}^{1-\alpha}+p\left(v_{m t}\right) A\left(\lambda k_{i m t}\right)^{\alpha} l_{i m t}^{\alpha-1},
$$

where $p\left(v_{m t}\right)$ is a number between 0 and 1 and represents the probability of having a violent attack in municipality $m$ at time $t$. Having a positive probability that violent acts destroy infrastructure makes investment and hiring decisions harder and riskier. In some cases agents may rationally decide to reduce long term investments in factors of production in order to reduce the exposure of their wealth or reduce ties to that specific region. Another way to see it is that firms in a violent context not only need to be efficient in terms of production, but they should have some characteristics that help their factors of production survive to violent environments.

Under these assumptions it can be easily shown that conflict will reduce a firm's output. Holding that with a higher probability of having a violent attack production will reduce $\frac{\partial Y_{i m t}}{\partial p\left(v_{m t}\right)}<0$

Although this relationship between violence and production is clear the effect that violence can have on a firm's exit decision is not necessarily obvious and hence the model needs to be extended. Under a traditional perfect competition model we know a firm will decide to exit the market if it cannot cover its fixed costs $(F C)$. That is, if we define exit as a dummy variable equal to 1 if the firm decides to exit and 0 otherwise we will have:

9 We do not explicitly assume the firm will suffer a labor demand shock due to violence. However, the optimal labor demand will of course be different under armed conflict when the firm maximizes profits. 


$$
\text { exit }=\left\{\begin{array}{l}
1 \text { if } \pi<-F C \\
0 \text { if } \pi \geq-F C
\end{array}\right\}
$$

Benefits will be given by the difference between income and variable (VC) and FC:

$$
\pi=P Y-V C-F C
$$

where fixed costs include the capital stock $\left(k_{t}\right)$ and variable costs include payroll $\left(w l_{t}\right)$, intermediate consumption goods $(I C)$ and investments in period $t\left(I_{t}\right)$ :

$$
F C=r(1-\delta) K_{t-1} \quad \text { and } \quad V C=w L_{t}+r I_{t}+I C
$$

Replacing fixed and variable costs in equation (3) we get:

$$
\pi=P Y-w L_{t}-r I_{t}-I C-r(1-\delta) K_{t-1}
$$

If we allow revenue $(P Y)$ minus intermediate consumption (IC) to be total value added (VA) and replace it in (2) we obtain that:

$$
\text { exit }=\left\{\begin{array}{l}
1 \text { if } V A-w L_{t}-r I_{t}<0 \\
0 \text { if } V A-w L_{t}-r I_{t} \geq 0
\end{array}\right\}
$$

Now the effect that violence can have over firms' exit decisions becomes ambiguous. On the one side, as shown above, it will definitely reduce a firm's value added through a reduction in production. However, violence will also influence the optimal labor the firm demands, given its effect on the marginal product of capital and hence will reduce part of its variable costs.10 Moreover, violence could have a positive or a negative effect on investment. For fear motives firms may desire to cut back investments. However, if any attack destroys necessary capital firms will need to replace it and investment will necessarily increase. Under these circumstances, the effect of violence on firms' exit decision may be unclear and the answer needs to be obtained empirically.

\section{Empirical Strategy}

Having in mind the channels above described, this paper empirically estimates the effect that armed conflict has over firm exit decisions for all Colombian manufacturing plants in the AMS between 1993 and 2004. Based on the model described in the previous section, we have that the reduced form of such decision will be given by:

$$
\text { exit }=f\left(V A, w L_{t}, r I_{t}, v i o\right)
$$

10 Here of course we are assuming that wages are fixed as in a competitive model. In the empirical part we do not have this restrictive assumption given that we will control for labor costs, wages and number of laborers. 
This is the basic structure that all the estimations presented in this paper will have. The use of the unique data described in section 3 will allow us to use panel data techniques to answer our question of interest. As it is well known, this technique is highly valuable given that, among other things, it allows the researcher to control for all the constant unobservables that could affect the outcomes of interest. For our specific case, panel data techniques could for instance control for the managerial abilities or political affiliation of the owners of firms that will indeed influence the decisions taken and hence the results attained by them.

Specifically, the simplest specification that we estimate is given by:

$$
y_{i, m, t}=\beta_{0}+\beta_{1} v_{m, t}+\beta_{3} d_{i, m, t}+\beta_{4} x_{m, t}+\beta_{5} f_{i, m, t}+\gamma_{t}+\delta_{i}+u_{i, m, t}
$$

where $y_{i, m, t}$ represents the exit decisions for firm $i$ located in municipality $m$ and at time $t$. The variable $V_{m, t}$ represents the violence or armed conflict that took place in municipality $m$ and at time $t$. As specified above, this variable captures the rate of attacks perpetrated by all the armed groups active inside Colombian borders in the period of study. We include $d_{i, m, t}$ as a variable that capture duration of the firm in the panel. The vector $x_{m, t}$ represents constant and time varying municipal characteristics such as the municipality area, the distance to the main city in the municipality, the GDP of the state, and transferences from the Central Government. The vector $f_{i, m, t}$ represents firm characteristics changing over time, such as nominal investment, total nominal wages paid and added value all of which come from our theoretical model. Finally, $\gamma_{t}, \delta_{i}$ represent year- and plant-fixed effects, respectively, and $\mu_{i, m, t}$ is an error term assumed to be orthogonal to firm exit.

Under specification (8), $\beta_{1}$ is our coefficient of interest which will give an estimate of the effect that armed conflict has on plant exit. However, one must be cautious when interpreting this result, given that reverse causality and endogeneity could be biasing our estimation of $\beta_{1}$. A growing literature has previously shown that economic activity is an important determinant on the onset and duration of civil conflict. Among some of these studies we find Collier and Hoeffer (2002), Fearon and Laitin (2003), and Miguel, Statyanath, and Sergenti (2004)_all using cross-country information-have found that levels and growth rates of GDP have a negative effect on armed conflict measures. There are many channels through which such reverse causality could emerge. For instance, lower economic activity may be associated with fewer labor opportunities or lower wages for young men. Under such scenarios it would be easier for armed groups to recruit new members and an escalation of the conflict could take place. Another possibility is that a firm's location is endogenous to levels of violence. A firm will take into account violence conditions when deciding whether to open business or not. The strongest or more able firms to face conflict will open and stay. This will be tested in future work by estimating an equation for firm entry.

For the reasons previously explained we must take into account the possibility of endogeneity in our conflict measure $v_{m, t}$. To do so we follow two different strategies: the first one is to use lagged, instead of contemporaneous, measures of armed conflict $\left(v_{m, t-1}\right)$ as follows: 


$$
y_{i, m, t}=\beta_{0}+\beta_{1} v_{m, t-1}+\beta_{3} d_{i, m, t}+\beta_{4} x_{m, t}+\beta_{5} f_{i, m, t}+\gamma_{t}+\delta_{i}+u_{i, m, t} .
$$

It is plausible to assume that firm managers will take into account the last period's armed conflict intensity when making production decisions today or even entering into business. However, it is harder to come up with a story where production decisions of today will influence armed activity yesterday, eliminating possible reverse causality problems. 11 However, the problem with this approach is that if there is any inertia in the armed conflict measure or in economic activity lagged measures of the former will not necessarily solve the endogeneity problem.

Hence, the second strategy is an instrumental variables approach in which we explain the armed conflict present in municipality $m$ at time $t$ with lagged laboratories dismantle $z_{1 m t}$ and anti-narcotics operations $z_{2 m t}$ in municipality $m$ at time $t$. Our first stage will be given by the following equation:

$$
v_{m, t}=\partial_{0}+\partial_{1} z_{1 m, t}+\partial_{2} z_{2 m, t}+\beta_{3} d_{i, m, t}+\beta_{4} x_{m, t}+\beta_{5} f_{i, m, t}+\gamma_{t}+\delta_{i}+u_{i, m, t}
$$

where violence in municipality $m$ at time $t$ is explained by all the exogenous regressors. We used these two instruments for two main reasons. First, the laboratories dismantle and antinarcotics operations rate in municipality $m$ at time $t$ should be highly correlated with armed conflict given that it serves as a measure of both the presence and effectiveness of the government to counteract criminal activity in the region. That is, we would expect to find a negative association between this government's deterrence measure and armed conflict intensity, as will be shown in our first stage regression. However, note that both variables are related to drug production which is known to be the main financing source of the Colombian armed groups. Hence, if these groups try to protect such laboratories or production sites through armed attacks it could also be the case that a positive relationship between armed conflict and such deterrence measures could emerge. The second reason behind our choice of instruments is that we believe in their exogeneity. It is hard to believe that production and commercial decisions of managers today will be based on these specific central government deterrence decisions which are normally secret operations that occur in environments not easily detected by the civil population.

It should be noted that a recent paper by Angrist and Kugler (2008) gives further support for our instruments. In their study, the authors find that indeed an exogenous upsurge in coca cultivation increased violence in the regions where it was produced. They explain that a possible mechanism through which this takes place is by the resources that drug production gives to Colombian armed groups. Furthermore, the authors also find little

11 Studies such as Collier and Hoeffer (2002) and Fearon and Laitin (2003) have previously used lagged independent variables to solve reverse causality problems between economic activity and armed conflict. However, as previously mentioned their interest is in understanding how the former affects the latter. As detailed in Miguel, Statyanath, and Sergenti (2004) under such question the use of lagged variables is more doubtful given that economic actors could anticipate the possible conflict. 
evidence to suggest that increased coca production benefited economic activity in the producing regions. Although the income of some rural dwellers increased, they argue that regional economies are not closely related to the drug business and that most of the resources from this activity go directly to the insurgent hands. Given that manufacturing is clearly a more urban and legal activity it is even harder to find channels through which antinarcotics deterrence actions should influence firm exit decisions.

The instrumental variable approach is our preferred estimation strategy, not only because it addresses the endogeneity problem directly, but also because it could reduce any possible bias due to measurement errors or omitted variables as well. Of course both requirements for a good set of instruments will be tested empirically. That is, we will need to prove that both deterrence measures are strongly related with our variable of interest and that they are exogenous to firms' exit decisions.

\section{Results}

A preview of our paper can be seen in Figure 3. It shows quintiles for the total attack rate and firm exit rate at the state level. We have information of entrepreneurial activity in most of the Colombian States, with the exception of three Eastern states. These are mainly rural states and hence it is not surprising that no manufacturing firm is located there. With some exceptions, the figure shows that in general there is a positive correlation between quintiles of firm exit proportion and attack rates. Of course, this simple relationship does not imply causality and more formal exercises as the ones described in the empirical strategy needed to be carried out. Different specifications of Equation (8 and 9) are presented in Table 3 as we gradually include controls into the regression. The first three columns are related with contemporaneous measures of armed conflict while the last three relate with lagged measures. Columns (1) and (4) include as controls only the duration variable as well as plant- and year-fixed effects; columns (2) and (5) add the municipal controls described above; and the last specifications include all the set of controls by adding firms' specific characteristics that arise from the model in section 4. Even though we are controlling for fixed effects at the plant level the second and third specifications are possible, given that out of the 12,714 plants, 862 of them changed location during the period under study. Finally we should note that by adding firms' controls such as value added, nominal investment, and total wages a significant number of observations are lost due to data restrictions.

As shown in all specifications presented in Table 3, the contemporaneous intensity of conflict appears to have no effect over plant exit. All coefficients of interest in these regressions are actually 0 . However, as described above, these results need to be interpreted with caution given the possible reverse causality that can exist between economic activity and armed conflict. The three last columns of Table 3 try to address the problem of reverse causality by using the lagged intensity of the conflict. As described above, while it is expected that economic activity of today could influence armed conflict today it is harder to believe that it could influence yesterday's armed conflict. However, as can be observed in Table 3 there still appears to be no effect of violence on firm exit decisions as the coefficient of interest across all specifications remain equal to 0 . 
From Table 3 it can also be observed that the longer a firm appears in the panel the more probable exit is. In general, firms located in municipalities where the local government receives higher transfers from the central government are less likely to exit. In regards to the plants' own characteristics we find that larger firms in terms of value added and those who have a bigger payroll have a lower probability of exiting. This result goes in line with those found in the exit literature such as Bernard and Jensen (2006) and Alvarez and Görg (2005) for the USA and Chile, respectively.

Even though the lag strategy could in principle solve the reverse causality between armed conflict and economic activity if there is any inertia in the latter variable lagged measures of past conflict may not be a truly an exogenous variable. This would imply that our coefficient of interest could still suffer from a significant bias problem. Hence, we also decided to implement an instrumental variable approach. Specifically, we evaluate the effect that armed conflict measures, instrumented by lagged laboratories dismantle and antinarcotics operations at the municipality level, has on entrepreneurial activities. This is our preferred strategy not only because it directly addresses the endogeneity problems but also because any bias due to omitted variables or measurement errors will also decrease.

Table 4 presents the first stage regression of the instrumental variable (IV) approach, to check the appropriateness of the instrument used. The first and second column of Table 4 present the instruments separately, while columns (3)-(6) present them jointly. For every specification, laboratories dismantle and antinarcotics operations of the previous period influence in a significant manner the level of armed conflict in the municipality independently of the controls used in the regressions. Moreover, the F-test shows that under these specifications we will not suffer from any weak instrument problem given that in each case the statistic is significantly higher than ten.

The last column of Table 4 presents the coefficients associated with our two instruments after including all control variables and fixed effects. We find that if laboratories dismantle increases in one unit our armed conflict measure increases in 0.128 units. For anti-narcotics operations, we find that if this variable increases in one unit, armed conflict measure decreases in 0.008 units. The specific fact that both deterrence measures have the opposite sign is something that can be easily explained. On the one hand, if the deterrence measures carried out by the government are effective and can be maintained, over time it is expected that they should reduce future conflict in the municipalities where they are applied. The positive sign, however, can also emerge, due to policy endogeneity. As mentioned before, Colombian armed groups financially depend on drug production and trafficking. Hence, it is expected that if the government tries to reduce such activities the guerrilla and paramilitary groups will increase the armed attacks in their location of interest and fight to maintain their illegal business. Independently of the story we experience, the important aspect of our instruments is that as demonstrated above they are highly correlated with our armed conflict measure.

Even though relevance of the instruments has been proven, we also need to address the exogeneity of our chosen instruments and the endogeneity of the armed conflict measure in the exit specification. Both these questions are answered in the lower panel of Table 5 which presents the results for the Sargan- and endogeneity test of the instruments and 
armed conflict, respectively. In the former test the null hypothesis is that, assuming that one of the instruments is exogenous, the second one is also exogenous. None of the Sargan-tests from different specifications in Table 5 reject the null hypothesis under a reasonable significance level. The null hypothesis of the endogeneity test is that the armed conflict measure is an exogenous variable in the empirical specification and hence no IV procedure should be needed. In this case however, we reject such hypothesis in all specifications with a one percent confidence level implying that an IV estimation is indeed needed. As mentioned, the possible endogeneity problem is that if economic or labor conditions are difficult in a given community and firms have to close their productive plants, laborers feeling discouraged may join the armed groups and increase the violence in the place where they reside.

The results of the second stage for the exit decision of plants are presented in Table 5 . Under the two stage procedure we can observe that armed conflict has a positive and significant effect on plant exit. Column (1) shows that after controlling only for plant-fixed effects, year effects and duration of the firms, the hazard rate that plant exits the market increases in 8.1 or 6.2 percentage points with a one standard deviation in the total attack rate or evaluated at the mean, respectively. Columns (2) and (3) of the same table show the results after including both municipalities' and firms' characteristics as control variables. As can be observed, the negative effect of armed conflict remains and is highly stable even though for the last specification we lose a significant number of observations. This negative effect is of course, at least in the short run, negative for the municipality's economy given that jobs will be lost and poverty could increase. Furthermore, precarious socio-economic conditions could lead to increases in armed conflict creating a vicious circle.

Finally, we also investigate whether certain types of manufacturing plants are more vulnerable to the negative effects of armed conflict than others. Specifically, we investigate whether the size or the age of the firm influence the magnitude of the effect of armed conflict on exit decisions. To answer the first question we divided the sample in three excluding groups according to the number of laborers each plant hires and ran the two-stage least square (2SLS) on each group separately. Specifically, the first group encompasses those firms that hire less than 500 laborers; the second group includes those that hire between 500 and 1000 laborers; while the third group encompasses the remaining plants. Each group contains 65.36 percent, 30.79 percent, and 3.84 percent of the total number of manufacturing plants, respectively. Table 6 shows that all the effect previously found appears to be driven mainly by the negative impact armed conflict has on small manufacturing plants.12 After including municipalities' and plants' characteristics the impact of one more attack on the exit probability of firms' increases in 4 percentage points. This last result goes in line with that found by Konrad and Skaperdas (1998) in which under extortion the smaller and less productive firms are the ones forced to exit the market.

12 For those firms with more than 1000 employees the last specification with firm controls is not reported in Table 6 given that we have perfect prediction. The reason for this is that there is no large firm with complete information that exited the market during our period of study. 
To analyse how the age of the firm may influence the armed conflict impact we also divided the sample into three groups, as follows: those firms younger than five years, those between five and ten years and those that were older than ten years. We then ran the 2SLS estimation on each group separately and the results of these estimations are presented in Table 7. Armed conflict appears to be increasing the likelihood of exit for either very young or very old firms. This could be explained by lack of experience and obsolescence, respectively, which could make them much more fragile and prone to armed conflict risks.

\section{Conclusion}

Using a combination of two unique data sets this paper estimates the effect that armed conflict has on exit decisions of manufacturing firms in Colombia. Having one of the longest ongoing civil conflicts in the world, Colombia is a good example to analyse this subject. Moreover, the availability of a panel data set at the plant level allows us to estimate how managers' and owners' decisions are influenced by civil conflict, a topic that has not been addressed before. Under an instrumental variable methodology, which controls for possible reverse causality problems, we find that armed conflict has a significant effect in the exit decisions of the plants. This effect appears to be larger for smaller, less experienced, or obsolete firms

The present research is a first step to fill an important gap in the conflict and economy literature. Contrary to previous studies based on cross-country information or aggregate variables such as GDP growth, we are able to understand which and how firms' decisions are influenced by armed conflict. These first results contribute to the understanding of the possible direct channels through which conflict influences economic activity. They also can enrich the knowledge of governments and NGOs in order to design suitable policies that aim to counteract the negative consequences of war and reduce its negative consequences on development.

This is a very young research question and hence further research is needed to understand the effect of conflict over other important entrepreneurial decisions. Among them we should mention the effect on capital stock and investment decisions, number of employees hired at the plants, the proportion of male and production laborers, and real wages paid by the firms.

\section{References}

Abadie, Alberto and Javier Gardeazabal. 2003. The economic costs of conflict: a case study of the Basque country. American Economic Review 93 (1): 133-32.

Alesina, Alberto, Sule Ozler, Nouriel Roubini and Philip Swagel. 1996. Political instability and economic growth. Journal of Economic Growth 1 (2): 189-211.

Alesina, Alberto and Roberto Perotti. 1996. Income distribution, political instability, and investment. European Economic Review 40 (6): 1203-28. 
Alvarez, Roberto and Holger Görg 2009. Multinationals and plant exit: evidence from Chile. International Review of Economics \& Finance 18 (1): 45-51.

Angrist, Joshua and Adriana D. Kugler. 2008. Rural windfall or a new resource curse? Coca, income, and civil conflict in Colombia. The Review of Economics and Statistics 90 (2): 191-215.

Arias, Andrés and Laura Ardila. 2003. Military expenditure and economic activity: the Colombian case. Documento CEDE 2003-20. Bogotá: Universidad de los Andes.

Audretsch, David B. and Talat Mahmood. 1995. New firm survival: new results using a hazard function. The Review of Economics and Statistics 77 (1): 97-103.

Barro, Robert. 1991. Economic growth in a cross-section of countries. Quarterly Journal of Economics 106: 404-44.

Bernard, Andrew B. and Bradford Jensen. 2006. Firm structure, multinationals, and manufacturing plant deaths. Working Paper WP06-7. Washington, DC: Peterson Institute.

Cárdenas, Mauricio. 2007. Economic growth in Colombia: a reversal of 'fortune'? Ensayos Sobre Política Económica. Banco de la República - ESPE.

Camacho, Adriana. 2008. Stress and birth weight: evidence from terrorist attacks. American Economic Review 9 (2): 511-15.

Collier, Paul. 1999. On the economic consequences of civil war. Oxford Economic Papers 50 (4): 563-73.

Collier, Paul and Anke Hoeffler. 2002. On the incidence of civil war in Africa. Journal of Conflict Resolution 46 (1): 13-28.

Eslava, Marcela, John Haltiwanger, Adriana Kugler, and Maurice Kugler. 2004. The effects of structural reforms on productivity and profitability enhancing reallocation: evidence from Colombia. Journal of Development Economics 75: 333-71.

— . 2008. Trade reforms and market selection: evidence from manufacturing plants in Colombia. Working paper. Bogotá: Universidad de los Andes.

Fearon, James D. and David D. Laitin. 2003. Ethnicity, insurgency, and civil war. American Political Science Review 97 (1): 75-90.

Gaviria, Alejandro. 2002. Assessing the effects of corruption and crime on firm performance: evidence from Latin America. Emerging Markets Review 3 (3): 245-68.

Grun, Rebekka. 2008. Household investment under violence - the Colombian case. Policy Research Working Paper 4713. Washington, DC: World Bank.

Harbom, Lotta and Peter Wallensteen. 2007. Armed conflict, 1989-2006. Journal of Peace Research 44 (5): 623-34. 
Ibáñez, Anamaria and Carlos Eduardo Vélez. 2005. Civil conflict and forced migration: the micro determinants and the welfare losses of displacement in Colombia. Documento CEDE 2005-35. Bogotá: Universidad de los Andes.

Iyigun, Murat and Dani Rodrik. 2004. On the efficiency of reforms: political tinkering, institutional change and entrepreneurship. Working Paper 10455. Cambridge, MA: National Bureau of Economic Research.

Konrad, Kai A. and Stergios Skarpedas. 1998. Extortion. Economica 65 (260): 461-77.

Mejia, Daniel and Carlos Posada. 2003. Capital destruction, optimal defense and economic growth. Borradores de Economía 257. Bogotá: Banco de la República.

Miguel, Edward, Shanker Statyanath, and Ernest Sergenti. 2004. Economic shocks and civil conflict: an instrumental variables approach. Journal of Political Economy 112 (4): $725-53$.

Morrison, Andrew R. and Rachel A. May. 1994. Escape from terror: violence and migration in post-revolutionary Guatemala. Latin America Research Review 29 (2): $111-32$.

Munshi, Kaiva. 2007. From farming to international business: the social auspices of entrepreneurship in a growing economy. Working Paper 13065. Cambridge, MA: National Bureau of Economic Research.

Pshisva, Rony and Gustavo Suarez. 2006. Captive markets: The impact of kidnappings on corporate investment in Colombia. Working Paper 2006-18. Washington, DC: FEDS.

Querubín, Pablo. 2003. Crecimiento departamental y violencia criminal en Colombia. Documento CEDE 2003-12. Bogotá: Universidad de los Andes.

Rettberg, Angelika. 2008. Explorando el dividendo de la paz: impactos del conflicto armado en el sector privado Colombiano, resultados de una encuesta nacional. CESO, Ediciones Uniandes. Bogota: Universidad de los Andes.

Riascos, Alvaro and Juan F. Vargas. 2004. Violence and growth in Colombia: a brief review of the literature. Available at: www.webpondo.org.

Rodriguez, Catherine and Fabio Sanchez. 2009. Armed conflict exposure, human capital investments and child labor: evidence from Colombia. Documento CEDE 005400. Bogotá: Universidad de los Andes.

Rubio, Mauricio. 1995. Crimen y crecimiento en Colombia. Coyuntura Económica XXV (1):. 101-4.

Shemyakina, Olga. 2006. The effect of armed conflict on accumulation of schooling: results from Tajikistan. HiCN Working Paper 12.

Stewart, Frances, Cindy Huang, and Michael Wang. 2001. Internal wars: an empirical overview of the economic and social consequences, war and underdevelopment. In The Economic and Social Consequences of Conflict, Volume 1, eds F. Stewart and V. Fitzgerald. Oxford: Oxford University Press. 
Trujillo, Edgar and Marta Badel. 1998. Los costos económicos de la criminalidad y la violencia en Colombia: 1991-1996. Archivos de Macroeconomía. Documento 76. Bogotá: Departamento Nacional de Planeación.

Vargas, Juan Fernando. 2003. Conflicto interno y crecimiento económico en Colombia. Tesis PEG. Bogotá: Universidad de los Andes.

Verwimp, Phillip and Tom Bundervoet. 2008. Consumption growth, household splits and civil war. Research Working Paper 9. Brighton: MICROCON. 
Table 1: Number of firms and firms that exit by year

\begin{tabular}{ccc}
\hline Year & Number of firms & Firms that exit \\
\hline 1993 & 7,660 & 473 \\
1994 & 7,487 & 462 \\
1995 & 7,908 & 427 \\
1996 & 8,173 & 452 \\
1997 & 8,323 & 711 \\
1998 & 7,863 & 462 \\
1999 & 7,441 & 352 \\
2000 & 7,986 & 485 \\
2001 & 7,631 & 365 \\
2002 & 7,543 & 577 \\
2003 & 7,645 & 368 \\
2004 & 7,528 & 296 \\
Total & 93,188 & 5,430 \\
\hline
\end{tabular}

Source: DANE, AMS1993-2004.

Authors' calculations.

Table 2: Annual manufacturing survey, armed conflict, geographic and firm controls-descriptive statistics

\begin{tabular}{lccccc}
\hline & Obs. & Mean & St. Dev & Min. & Max. \\
\hline Firm exit proportion (\%) & 93,188 & 5.83 & 23.43 & 0.00 & 100.00 \\
Total attack rate (per 100,000 inhabitants) & 93,188 & 2.42 & 3.14 & 0.00 & 154.61 \\
Municipality surface $\left(1000 \mathrm{~km}^{2}\right)$ & 93,188 & 0.84 & 0.72 & 0.02 & 6.79 \\
$\quad$ Average distance to largest city (1000 km) & 93,188 & 0.05 & 0.10 & 0.00 & 1.03 \\
$\quad$ State's GDP (per capita Real prices (1994) & 93,188 & 2.14 & 0.53 & 0.55 & 7.48 \\
$\quad$ millions Colombian pesos) & 93,188 & 0.16 & 0.25 & 0.00 & 0.96 \\
$\quad$ Transferences (trillions Colombian pesos) & & & & & \\
Ln Total Nominal Wage Paid (thousands & 89,617 & 11.66 & 1.53 & 0.00 & 18.03 \\
$\quad$ Colombian pesos) & & & & & \\
Ln nominal investment (thousands Colombian & 51,127 & 9.50 & 4.94 & -17.48 & 20.59 \\
$\quad$ pesos) & 49,997 & 12.86 & 1.91 & 3.78 & 19.97 \\
Ln added value (thousands Colombian pesos) & 93,188 & 6.84 & 9.72 & 0.00 & 44.00 \\
Anti-narcotics operations $(t-1)$ & 93,188 & 1.21 & 1.70 & 0.00 & 21.00 \\
Laboratories dismantle $(t-1)$ & & & &
\end{tabular}

Source: DANE, AMS1993-2004, CEDE.

Authors' calculations. 
Table 3: Effect of contemporaneous and lagged armed conflict measures on exit

\begin{tabular}{|c|c|c|c|c|c|c|}
\hline Dependent variable & $\begin{array}{l}\text { Exit-duration } \\
\qquad(1)\end{array}$ & $(2)$ & (3) & $(4)$ & $(5)$ & $(6)$ \\
\hline \multirow[t]{2}{*}{ Total attack rate } & 0.0001 & 0.0000 & 0.0004 & & & \\
\hline & [0.0003] & [0.0003] & {$[0.0004]$} & & & \\
\hline \multirow[t]{2}{*}{ Total attack rate $(t-1)$} & & & & 0.0002 & 0.0001 & 0.0000 \\
\hline & & & & [0.0003] & [0.0003] & [0.0003] \\
\hline \multirow[t]{2}{*}{ Duration } & $0.015^{\star \star \star}$ & $0.015^{\star \star \star}$ & $0.017^{\star \star \star}$ & $0.015^{\star \star \star}$ & $0.015^{\star \star \star}$ & $0.017^{\star \star \star}$ \\
\hline & {$[0.000]$} & {$[0.000]$} & {$[0.001]$} & {$[0.000]$} & {$[0.000]$} & {$[0.001]$} \\
\hline \multirow[t]{2}{*}{ Market distance } & & $-0.247^{\star *}$ & -0.177 & & $-0.245^{\star \star}$ & -0.182 \\
\hline & & {$[0.124]$} & {$[0.306]$} & & {$[0.124]$} & {$[0.306]$} \\
\hline \multirow[t]{2}{*}{ Municipality surface } & & 0.007 & -0.02 & & 0.007 & -0.02 \\
\hline & & [0.008] & {$[0.017]$} & & [0.008] & {$[0.017]$} \\
\hline \multirow[t]{2}{*}{ Transferences } & & $-0.021^{* \star *}$ & $-0.014^{\star \star}$ & & $-0.021^{\star * *}$ & $-0.014^{\star \star}$ \\
\hline & & {$[0.006]$} & {$[0.007]$} & & {$[0.006]$} & {$[0.007]$} \\
\hline \multirow[t]{2}{*}{ State's GDP } & & 0.007 & 0.012 & & 0.007 & 0.011 \\
\hline & & {$[0.007]$} & [0.010] & & {$[0.007]$} & [0.010] \\
\hline \multirow[t]{2}{*}{ Ln nominal investment } & & & 0 & & & 0 \\
\hline & & & [0.000] & & & {$[0.000]$} \\
\hline \multirow[t]{2}{*}{ Ln total wages } & & & $-0.045^{\star \star \star}$ & & & $-0.045^{\star \star \star}$ \\
\hline & & & {$[0.004]$} & & & [0.004] \\
\hline \multirow[t]{2}{*}{ Ln added value } & & & $-0.023^{\star \star \star}$ & & & $-0.023^{\star \star *}$ \\
\hline & & & [0.002] & & & [0.002] \\
\hline Firm-fixed effects & Yes & Yes & Yes & Yes & Yes & Yes \\
\hline Year-fixed effects & Yes & Yes & Yes & Yes & Yes & Yes \\
\hline Municipality controls & & Yes & Yes & & Yes & Yes \\
\hline Firm controls & & & Yes & & & Yes \\
\hline Observations & 93,188 & 93,188 & 37,018 & 93,188 & 93,188 & 37,018 \\
\hline
\end{tabular}

Note: Clustered standard errors by firm in brackets.

* significant at $10 \%$; ** significant at $5 \%$; $* *$ significant at $1 \%$.

Source: DANE, AMS1993-2004, CEDE.

Authors' calculations. 
Table 4: First stage regressions

\begin{tabular}{|c|c|c|c|c|c|c|}
\hline \multirow[t]{2}{*}{ Dependent variable } & \multicolumn{6}{|c|}{ Total attack rate } \\
\hline & (1) & $(2)$ & $(3)$ & $(4)$ & $(5)$ & (6) \\
\hline \multirow[t]{2}{*}{ Laboratories dismantle $(t-1)$} & $0.026^{\star \star \star}$ & & $0.072^{\star \star \star}$ & $0.098^{\star \star \star}$ & $0.135^{\star \star \star}$ & $0.128^{\star \star \star}$ \\
\hline & {$[0.007]$} & & {$[0.007]$} & {$[0.008]$} & [0.013] & {$[0.016]$} \\
\hline \multirow[t]{2}{*}{ Anti-narcotics operations $(t-1)$} & & $-0.021^{\star \star \star}$ & $-0.025^{\star \star \star}$ & $0.006^{\star \star \star}$ & $-0.007^{\star \star \star}$ & $-0.008^{\star \star \star}$ \\
\hline & & {$[0.001]$} & {$[0.002]$} & {$[0.001]$} & {$[0.001]$} & [0.002] \\
\hline F-excluded instruments & 13.36 & 202.50 & 154.50 & 75.03 & 61.36 & 34.72 \\
\hline$p$-value & 0.000 & 0.000 & 0.000 & 0.000 & 0.000 & 0.000 \\
\hline Firm-fixed effects & & & & Yes & Yes & Yes \\
\hline Year-fixed effects & & & & Yes & Yes & Yes \\
\hline Municipality controls & & & & & Yes & Yes \\
\hline Firm controls & & & & & & Yes \\
\hline Observations & 93,188 & 93,188 & 93,188 & 93,188 & 93,188 & 37,020 \\
\hline Notes: $\mathrm{Cl}$ & firm in bra & ets. & +106 & & & \\
\hline
\end{tabular}


Table 5: IV results of contemporaneous armed conflict measures on exit

\begin{tabular}{|c|c|c|c|}
\hline $\begin{array}{l}\text { Instruments } \\
\text { Dependent variable }\end{array}$ & \multicolumn{2}{|c|}{$\begin{array}{l}\text { Laboratories dismantle anti-narcotics } \\
\text { operations }\end{array}$} & otics \\
\hline Total attack rate & $\begin{array}{l}0.026 * \star \star \\
{[0.006]}\end{array}$ & $\begin{array}{l}0.019 * \star \star \\
{[0.005]}\end{array}$ & $\begin{array}{l}0.026^{* * *} \\
{[0.008]}\end{array}$ \\
\hline Duration & $\begin{array}{l}0.015^{\star \star \star} \\
{[0.000]}\end{array}$ & $\begin{array}{l}0.014^{\star \star \star} \\
{[0.000]}\end{array}$ & $\begin{array}{l}0.016^{* * *} \\
{[0.001]}\end{array}$ \\
\hline Market distance & & $\begin{array}{r}-0.083 \\
{[0.147]}\end{array}$ & $\begin{array}{c}0.18 \\
{[0.344]}\end{array}$ \\
\hline Municipality surface & & $\begin{array}{c}-0.01 \\
{[0.010]}\end{array}$ & $\begin{array}{l}-0.040^{\star} \\
{[0.020]}\end{array}$ \\
\hline Transferences & & $\begin{array}{c}0.006 \\
{[0.009]}\end{array}$ & $\begin{array}{c}0.018 \\
{[0.011]}\end{array}$ \\
\hline State's GDP & & $\begin{array}{l}0.029 \star \star \star \\
{[0.009]}\end{array}$ & $\begin{array}{l}0.035^{\star * *} \\
{[0.013]}\end{array}$ \\
\hline Ln nominal investment & & & $\begin{array}{c}0 \\
{[0.000]}\end{array}$ \\
\hline Ln total nominal wages & & & $\begin{array}{c}-0.043^{\star \star *} \\
{[0.004]}\end{array}$ \\
\hline Ln added value & & & $\begin{array}{c}-0.024^{\star \star \star} \\
{[0.003]}\end{array}$ \\
\hline Sargan-test & & & \\
\hline Chi-sq(1) & 0.261 & 0.024 & 0.314 \\
\hline$p$-value & 0.610 & 0.877 & 0.575 \\
\hline Endogeneity test & & & \\
\hline Chi-sq (1) & 18.915 & 14.574 & 12.798 \\
\hline p-value & 0.000 & 0.000 & 0.000 \\
\hline Firm-fixed effects & Yes & Yes & Yes \\
\hline Year-fixed effects & Yes & Yes & Yes \\
\hline Municipality controls & & Yes & Yes \\
\hline Firm controls & & & Yes \\
\hline Observations & 92,096 & 92,096 & 36,233 \\
\hline
\end{tabular}

Note: Clustered standard errors by firm in brackets.

* significant at $10 \%$; ** significant at $5 \%$; *** significant at $1 \%$.

Source: DANE, AMS1993-2004, CEDE.

Authors' calculations. 
Table 6: IV Results of contemporaneous armed conflict measures on exit by size

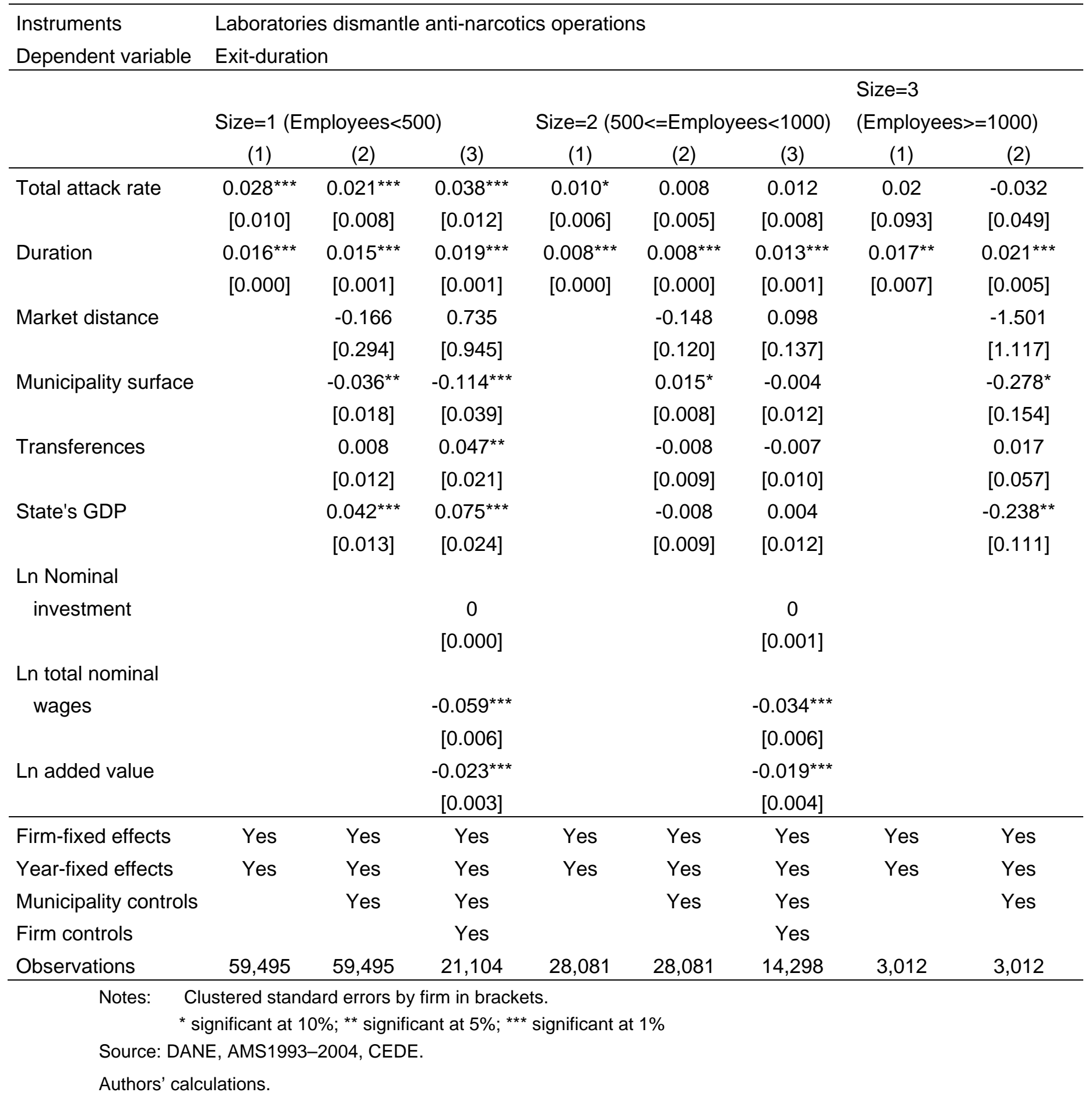


Table 7: IV results of contemporaneous armed conflict measures on exit by age

\begin{tabular}{|c|c|c|c|c|c|c|c|c|c|}
\hline \multirow{4}{*}{$\begin{array}{l}\text { Instruments } \\
\text { Dependent variable }\end{array}$} & \multicolumn{9}{|c|}{ Laboratories dismantle anti-narcotics operations } \\
\hline & \multicolumn{9}{|c|}{ Exit-duration } \\
\hline & \multicolumn{2}{|c|}{ Age $=1(<5)$} & \multicolumn{4}{|c|}{$\operatorname{Age}=2(>=5 \&<10)$} & \multicolumn{2}{|c|}{ Age $=3(>=10)$} & \multirow[b]{2}{*}{$(3)$} \\
\hline & $(1)$ & $(2)$ & $(3)$ & $(1)$ & $(2)$ & $(3)$ & $(1)$ & $(2)$ & \\
\hline \multirow[t]{2}{*}{ Total attack rate } & 0.023 & 0.015 & $0.041^{*}$ & 0 & 0.013 & -0.021 & $0.021^{* *}$ & $0.017^{* *}$ & $0.025^{\star * *}$ \\
\hline & [0.015] & [0.014] & [0.021] & [0.054] & {$[0.050]$} & [0.102] & [0.009] & {$[0.007]$} & {$[0.008]$} \\
\hline \multirow[t]{2}{*}{ Market distance } & & 0.372 & 1.807 & & -0.768 & -3.197 & & -0.228 & 0.07 \\
\hline & & [0.302] & [2.258] & & [0.629] & [2.108] & & {$[0.208]$} & {$[0.364]$} \\
\hline \multirow[t]{2}{*}{ Municipality surface } & & -0.019 & -0.118 & & 0.012 & 0.02 & & -0.009 & -0.029 \\
\hline & & [0.019] & {$[0.111]$} & & [0.052] & {$[0.131]$} & & {$[0.015]$} & {$[0.025]$} \\
\hline \multirow[t]{2}{*}{ Transferences } & & 0.013 & 0.082 & & -0.041 & -0.078 & & 0.006 & $0.022^{\star \star}$ \\
\hline & & {$[0.027]$} & {$[0.060]$} & & {$[0.040]$} & {$[0.116]$} & & [0.011] & {$[0.011]$} \\
\hline \multirow[t]{2}{*}{ State's GDP } & & $0.037^{*}$ & 0.014 & & -0.017 & -0.073 & & 0.014 & $0.036 * \star$ \\
\hline & & {$[0.020]$} & {$[0.050]$} & & [0.031] & {$[0.047]$} & & {$[0.013]$} & {$[0.016]$} \\
\hline \multirow[t]{2}{*}{ Ln nominal investment } & & & 0 & & & 0.001 & & & 0 \\
\hline & & & {$[0.001]$} & & & {$[0.001]$} & & & [0.000] \\
\hline \multirow[t]{2}{*}{ Ln total nominal wages } & & & $-0.048^{\star \star \star}$ & & & $-0.081^{\star \star \star}$ & & & $-0.047^{\star * *}$ \\
\hline & & & [0.013] & & & [0.015] & & & {$[0.004]$} \\
\hline \multirow[t]{2}{*}{ Ln added value } & & & $-0.033^{\star * \star}$ & & & $-0.024^{\star \star \star}$ & & & $-0.023^{\star \star \star}$ \\
\hline & & & {$[0.008]$} & & & {$[0.007]$} & & & [0.003] \\
\hline Firm-fixed effects & Yes & Yes & Yes & Yes & Yes & Yes & Yes & Yes & Yes \\
\hline Year-fixed effects & Yes & Yes & Yes & Yes & Yes & Yes & Yes & Yes & Yes \\
\hline Municipality controls & & Yes & Yes & & Yes & Yes & & Yes & Yes \\
\hline Firm controls & & & Yes & & & Yes & & & Yes \\
\hline Observations & 22,578 & 22,578 & 4,471 & 17,976 & 17,976 & 5,645 & 49,892 & 49,892 & 25,049 \\
\hline
\end{tabular}

Notes: Clustered standard errors by firm in brackets.

* significant at $10 \%$; ** significant at $5 \%$; ${ }^{* *}$ significant at $1 \%$

Source: DANE, AMS1993-2004, CEDE.

Authors' calculations. 
Figure 1: Total attack rate by municipalities (Colombia 1993-2004)

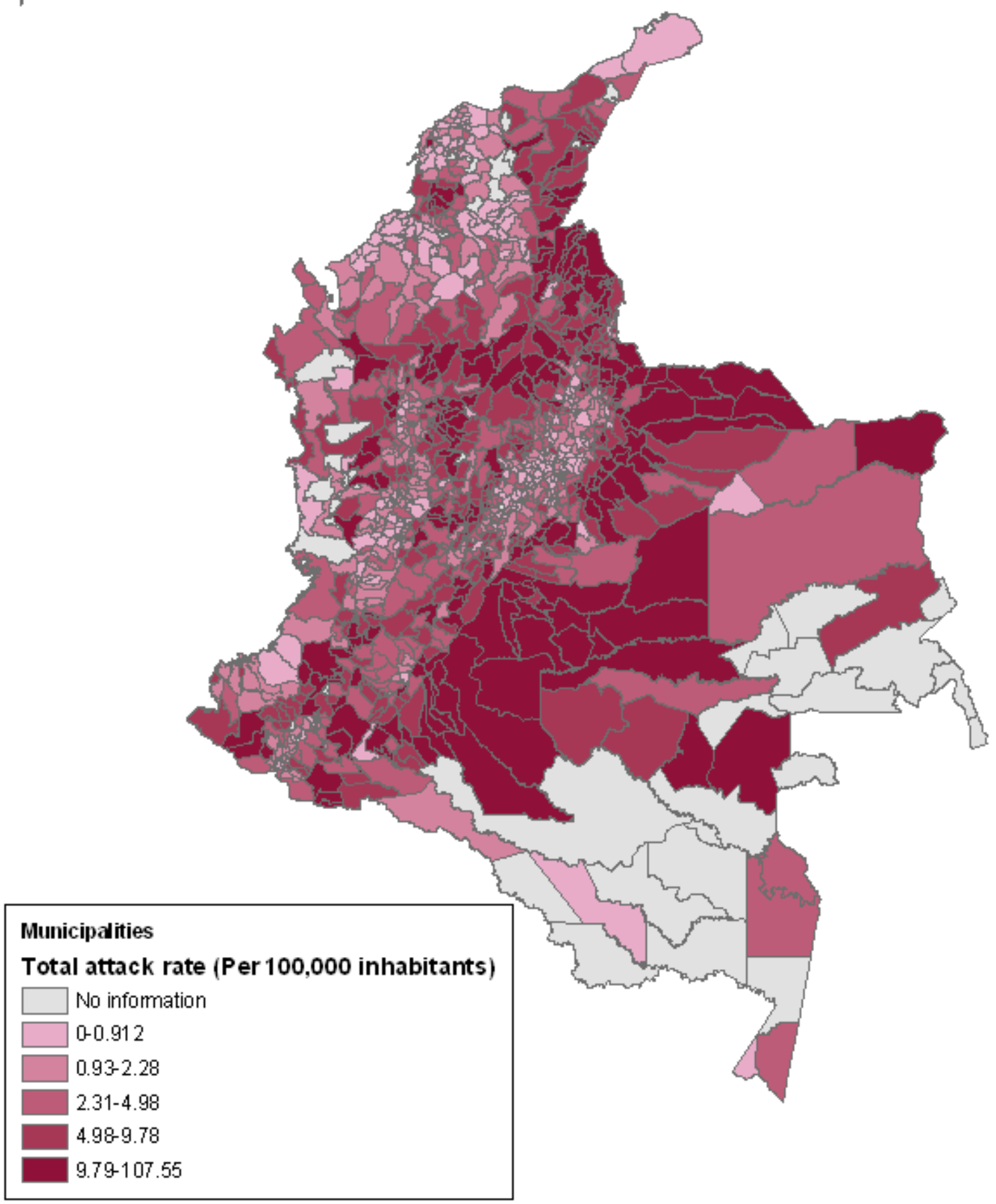

Source: DANE, AMS1993-2004. CEDE.

Authors' calculations. 
Figure 2: Total attack rate over time (per 100,000 inhabitants)

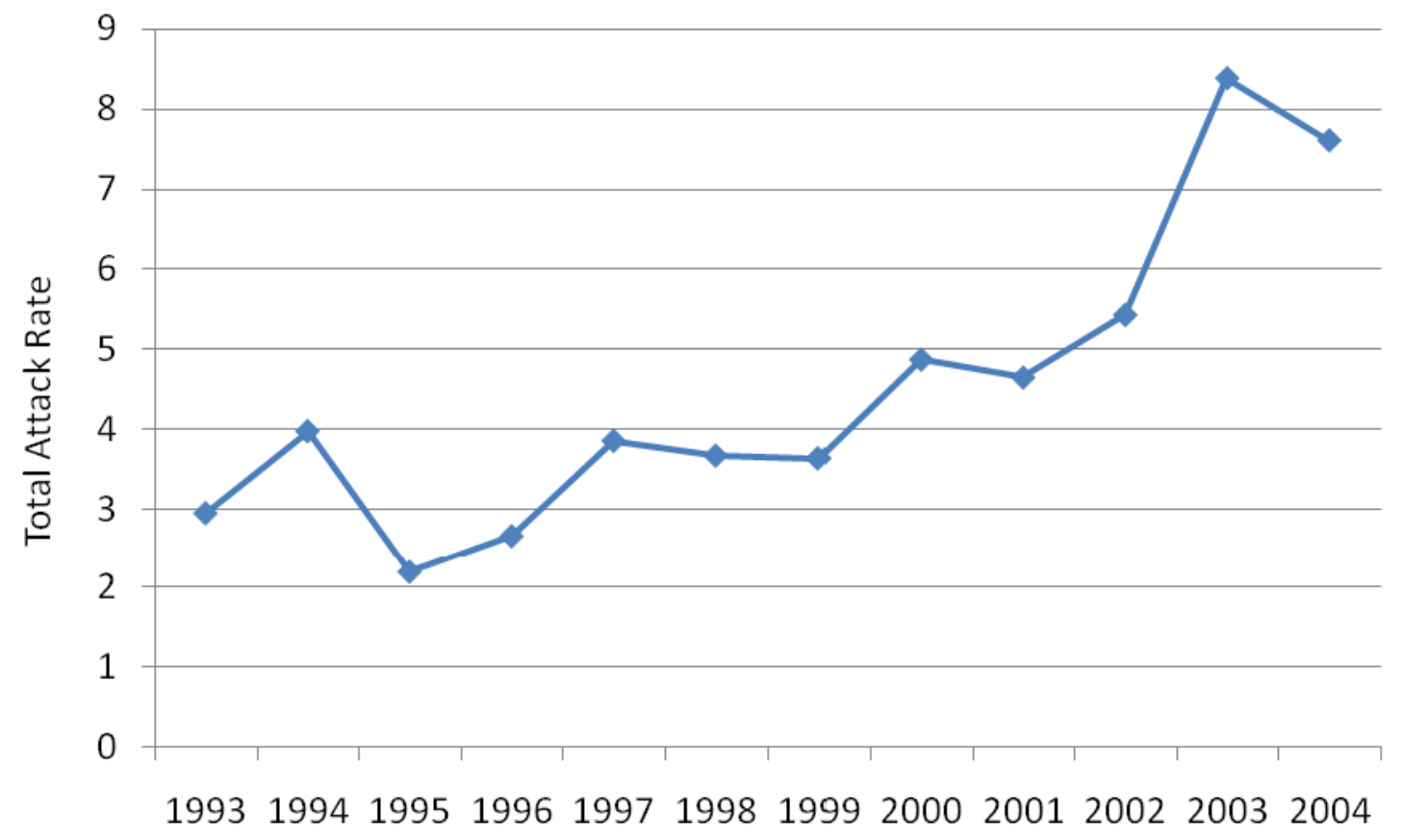


Figure 3: Total attack rate and firms' exit proportion by state (Colombia 1993-2004)

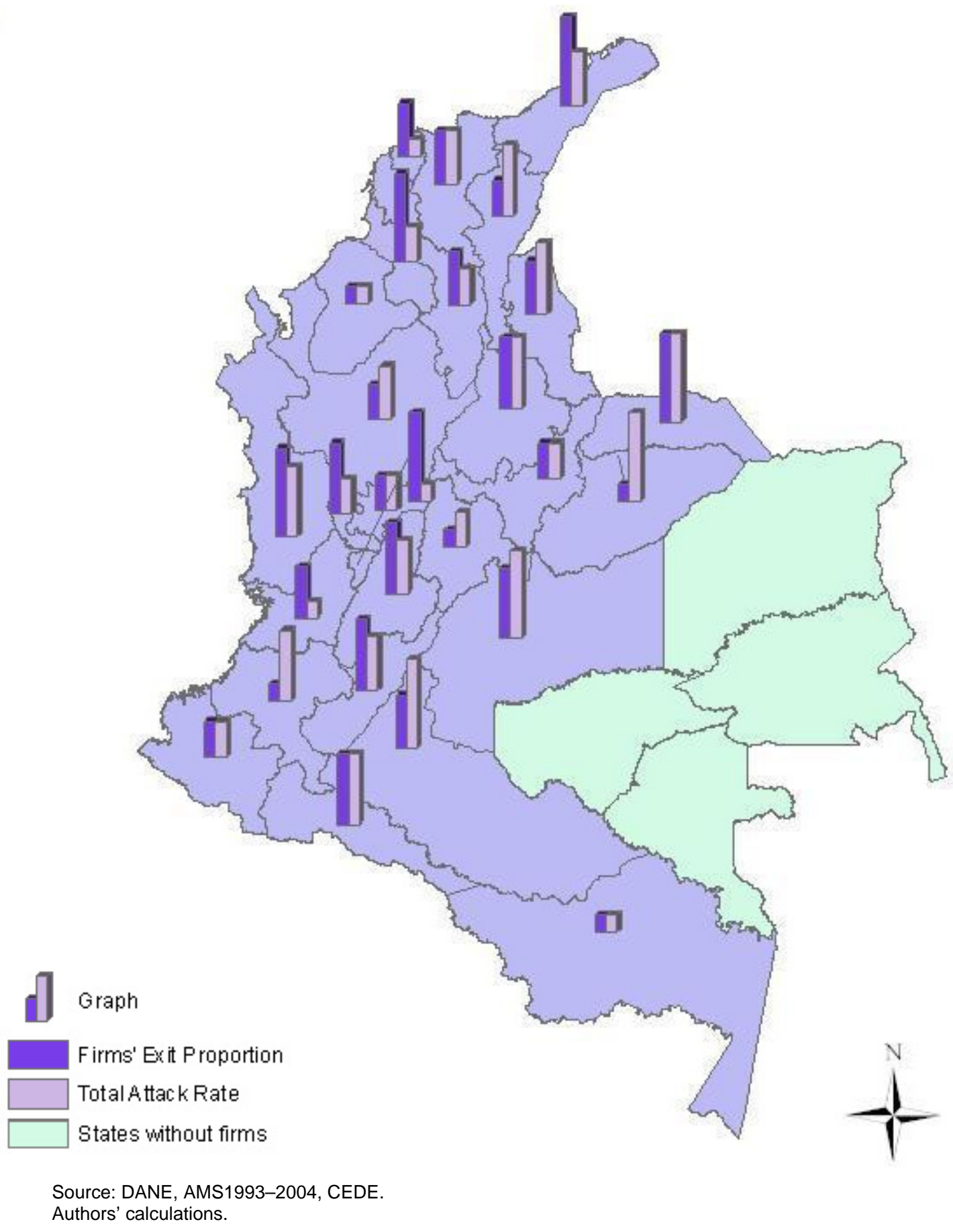

